\title{
COSMOPSALTRIA HALMAHERAE N. SP. ENDEMIC TO HALMAHERA, MALUKU, INDONESIA (HOMOPTERA, CICADIDAE)
}

\author{
The relationship of cicadas of Maluku Utara and Maluku Selatan
}

by

\section{J. P. DUFFELS}

Institute of Taxonomic Zoology, University of Amsterdam, Plantage Middenlaan 64, 1018 DH Amsterdam, The Netherlands

\section{ABSTRACT}

Cosmopsaltria halmaherae n. sp. is described from Halmahera, Maluku and placed in the $C$. doryca group. The characters of this group are reconsidered and the relationships of its members are discussed. The $C$. doryca group and two other monophyletic groups of cicadas demonstrate a vicariant distribution in Maluku Utara (= North Moluccas) and Maluku Selatan (= South Moluccas).

\section{RÉSUMÉ}

On décrit Cosmopsaltria halmaherae n. sp. de Halmahera, Maluku (Moluques), cette espèce étant placée dans le groupe $C$. doryca. Les caractères de ce groupe sont reconsidérés et les relations entre ses membres sont discutées. Le groupe doryca, ainsi que deux autres groupes monophylétiques de Cicades, montrent une distribution vicariante à Maluku Utara (= Moluques du Nord) et à Maluku Selatan (= Moluques du Sud).

\section{INTRODUCTION}

Study of the interesting cicada collections of the Museum Zoologicum Bogoriense, Bogor, Indonesia and the Senckenberg Museum, Frankfurt am Main, revealed an undescribed Cosmopsaltria species from the island of Halmahera.

Cosmopsaltria halmaherae, which is described as new to science in the present paper, must be attributed to the Cosmopsaltria doryca group, which was erected (Duffels, 1983: 47) for two species, $C$. doryca (Boisduval, 1835) the typespecies of the genus, and $C$. lata (Walker, 1868). $C$. doryca is a lowland species with a wide distribution in Ternate, Waigeo, Tjendrawasih (= Vogelkop of New Guinea), Japen Island and West New Guinea. C. lata is an endemic of
Buru and Ambon, Maluku Selatan (= South Moluccas).

The characters of the $C$. doryca group are reconsidered and a comparison of the species of the group makes plausible that $C$. halmaherae and $C$. lata must be regarded as sister-species. Their vicariant distribution in Maluku Utara (= North Moluccas) and Maluku Selatan is interesting from a biogeographic point of view, since a similar pattern is found in two other groups of cicadas.

\section{TAXONOMY}

\section{Cosmopsaltria halmaherae n. sp.}

(Figs. 1-4)

Distinction. - C. halmaherae is distinguished from $C$. lata by the fusion of the spots at the bases of the 2nd, 3rd, and 5th apical areas, as well as those at the bases of the 6th and 7th apical areas, which are separated in $C$. lata. $C$. doryca has only two spots at the bases of the 2 nd and 3rd apical areas, and no marginal spots as found in the other two species.

Material examined. - Holotype: "Goa Plains / 20.Sep.1951" (handwritten), “20.sept.1951 / Goa Plains" (print), $\sigma^{\circ}$, Museum Zoologicum Bogoriense (=MZB). Paratypes: Biaur, 600 m, 7-12.x.1951, $1 \sigma^{\circ}$, MZB; Mt. Sembilan, 600 m, 27.ix-6.x.1951, 1 \&, MZB; "Halmaheira / Galela, [18]94 / Kükenthal", "219", "Cosmopsaltria / capitata / Dist." (Distant's handwriting), $1 \sigma$, Senckenberg Museum, Frankfurt am Main (= SMF); "Halmaheira / Galela, [18]94 / Kükenthal", "Hochgebirg / 2200 Fuss / entsetzlich laute Stimme", "capitata / Distant", 10 , SMF. The two paratypes of the Senckenberg Museum have a shriveled thorax due to preservation in alcohol and are also otherwise in a poor condition. 
The type-localities Goa Plains, Biaur and Mt. Sembilan could not be traced until consultation of publications of the Dutch odonatologist M. A. Lieftinck (e.g. Lieftinck, 1953: 180) revealed that these localities (and others) were visited by the Sundanese collectors Amsari and Manis during an expedition in the island of Halmahera in September and October 1951. Localities, altitudes and dates of the types of $C$. halmaherae correspond with the data of Odonata studied by Lieftinck. This means that the cicadas were collected during the same expedition of Amsari and Manis in Halmahera. Some expedition localities which could be traced on topographic maps of Halmahera (1:500.000 and $1: 100.000)$ indicate that the expedition crossed the northern arm of Halmahera from the west to the east coast, north of the line Sahu-Kau and south of Ibu.

Description. - Head slightly narrower than pronotum. Ground colour of head and thorax brownish, mesonotum darker than head and pronotum. Marking dark brown to blackbrown. Abdomen dark brown to black.

Head: Dark brown rings encircle each of the ocelli. Broad undeep grooves on postclypeus underside sometimes darker than ridges and remaining surface of postclypeus. Black apex of rostrum reaching beyond hind coxae.

Thorax: Anterior and posterior oblique fissures and ambient fissure on pronotum dark brown. Mesonotum with dark brown to blackbrown marking which is fairly inconspicuous on the dark ground colour. Median fascia very narrow anteriorly, gradually widens to the posterior, where it attains greatest width at $1 / 2$ to $2 / 3$ the mesonotum length. Beyond its widest part, which is many times as wide as anterior width, the fascia either continues as a vague line to cruciform elevation or makes a vague connection with paramedian fasciae. Paramedian fasciae are as wide as anterior width of median fascia and converge slightly from anterior mesonotum margin to halfway the mesonotum disk. A pair of more or less round spots situated in front of cruciform elevation. Lateral fasciae very broad and vaguely dark brown clouded.

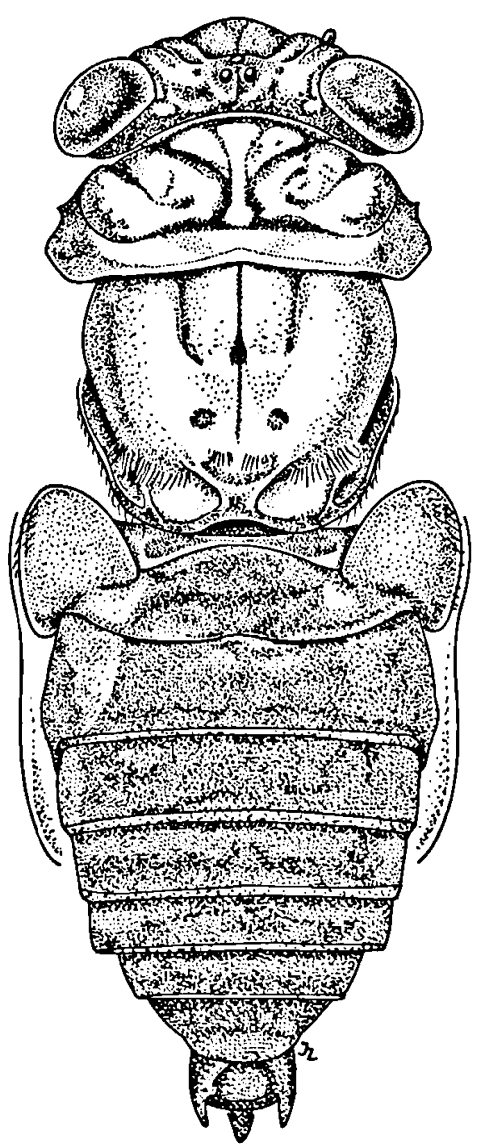

Fig. 1. Cosmopsaltria halmaherae, o paratype, Halmahera, Biaur.

Legs: Fore femora with some dark brown, longitudinal lines. Other femora and tibiae unmarked. Tarsi of fore and middle legs light brown, tarsi of hind legs yellowish.

Tegmina and wings: Tegmen long and slender, 3.1-3.2 times as long as high; 8 th apical area fairly long, length : width $\sigma^{\circ}$ 3.0-3.3 $(n=2)$, $93.1(n=1)$. Venation of tegmen and wing light brown, variegated with dark brown in apical half of tegmen. Basal veins of all apical areas broadly infuscated. Infuscations at bases of 2nd, 3rd, 4th and 5th apical areas and those at bases of 6 th and 7 th apical areas more or less confluent. The latter infuscation is in most specimens connected with infuscation along apical part of posterior vein of 7 th apical area. Marginal infuscations at apices of longitudinal veins very vague in tegmen apex but more welldefined posteriorly. 


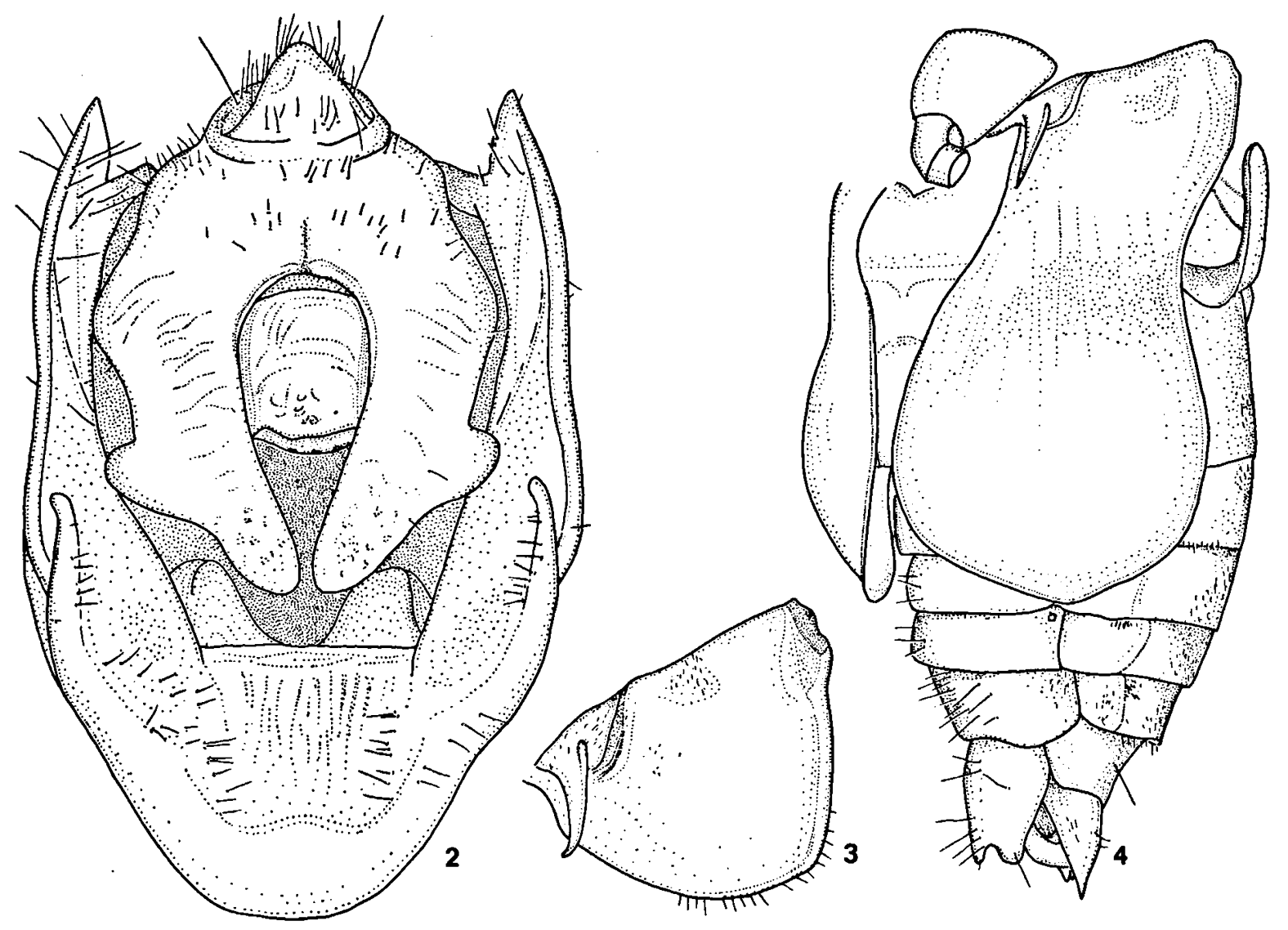

Figs. 2-4. Cosmopsaltria halmaherae: 2, pygofer in ventral view, holotype; 3, female operculum in ventrolateral view, paratype, Halmahera, Mt. Sembilan; 4, male abdomen with operculum in ventrolateral view, paratype, Halmahera, Biaur.

Male. - Operculum (fig. 4) broad, reaching to $2 / 3$ of the length of abdominal segment 5 or to anterior margin of segment 6, apical part broadly rounded. Lateral margin concavely sinuate at $2 / 5$ of its length and convexly curved in apical part. Operculum light brown; one paratype has a transverse dark-coloured fascia just behind the lateral incurvation; basal half of lateral margin dark brown. Abdomen dark castaneous, timbal coverings and sublateral parts of segment 3 light brown.

Genitalia (fig. 2): Pygofer slightly longer than broad. Lateral processes of pygofer short with sharply pointed apices, which reach as far distad as apices of anal valves. Uncus lobes are very broad at bases but gradually narrow to apices. Lateral margin of uncus lobe with very characteristic rounded protuberance. Median margin weakly concave. Apex of uncus lobe narrowly rounded. Clasper with short ligulate, basal part bearing a slightly curved, fairly strong, lateral spine and a curved medial spine, which is narrower and longer than the lateral one.

Female. - Operculum (fig. 3) brownish reaching to half length of segment 3 . Lateral margin nearly straight, basally very weakly sinuate and with a narrow, dark brown line. Laterodistal corner obtuse. Hind margin convex. Abdomen dark castaneous dorsally.

Measurements (in $\mathrm{mm}$; based on $40^{\circ} \mathrm{O}^{\circ}$ and 1 \%). Body length: $\sigma^{\prime}, 35.8-40.5 ; \propto, 37.2$. Tegmen length: $\sigma^{\circ}$, 51.0-53.0; $\&$, 55.0. Head width: $\sigma^{\circ}, 13.0-13.2$; $\$, 13.0$. Pronotum width: $\sigma, 13.6-14.2, \propto, 14.7$. Mesonotum width: $\sigma, 11.6-12.3$; $ᄋ, 12.8$. Head width : pronotum 
width, $\sigma$ 0.92-0.96, ९ 0.88. Head width : mesonotum width, $\sigma^{\circ} 1.07-1.12$, \& 1.02. Pronotum width : mesonotum width, ơ 1.15-1.17, \& 1.15 .

\section{PHYLOGENY}

\section{The Cosmopsaltria doryca group}

C. halmaherae has several features characteristic of the doryca group: the head is broad and slightly narrower than the pronotum, the uncus has a fairly small basal part and broad lobes and the inner ridges of the basal pygofer lobes are lacking. These features, however, have been regarded as synplesiomorphies for the doryca group; the multi-coloured male operculum was indicated as the only apomorphy for the species group (Duffels, 1983: fig. 8).

The discovery of the new species has led to re-consideration of the characters of the doryca group. $C$. doryca and $C$. lata have a multicoloured male operculum, but the operculum of C. halmaherae is brownish with, in one paratype, a darker coloured transverse fascia. The fairly uniform colour of the operculum of $C$. halmaherae might be due to discoloration, but the opercula of living specimens of this species are probably not so brightly multi-coloured as in the other two species of the group.

Re-study of the development of the uncus in the genus Cosmopsaltria led to the supposition that the broad, well-developed, more or less straight, uncus lobes as found in the three species of the doryca group must be regarded as apomorphous. Two more derived character states in the development of the uncus of Cosmopsaltria are (1) narrowing of the uncus lobes and elevation of the medial uncus part as found in the $C$. gracilis group, and (2) a very large basal uncus part with medially curved slender lobes as found in the mimica complex (Duffels, 1983: fig. 8).

\section{Infra-group relationships}

Speculation on the relationship of the three species of the $C$. doryca group is not so easy, the more so as the coloration of the male opercula of C. halmaherae is in fact unknown. C. lata and $C$. halmaherae have several characters in common: tegmen with infuscations at the bases of the 2nd, 3rd, 5th and 7th apical areas and a series of marginal spots, hardly recognizable or absent central fasciae on the pronotum, a dark castaneous male abdomen, and a very similar uncus lobe shape. $C$. doryca has only two spots on the tegmen at the bases of the 2nd and 3rd apical areas, very distinct, black central fasciae with a yellow interspace on the pronotum, a light to dark brown male abdomen with black marking and a broader, somewhat differently shaped uncus lobe. On account of this character matrix I regard $C$. halmaherae and $C$. lata as sister-species, although the distribution of the mentioned characters in the genus Cosmopsaltria and its sister-genera does not allow conclusions with regard to apomorphy or plesiomorphy of these characters.

\section{BIOGEOGRAPHY}

Sister-group relationships between representatives from Maluku Utara and Maluku Selatan in two monophyletic species groups were shortly mentioned in a previous discussion on the biogeography of the cicadas of Maluku Utara (Duffels, 1988).

The Diceropyga obtecta group, which comprises four species, contains three species from Maluku Utara: D. junctivitta (Walker, 1868) from Maluku Utara (Morotai, Halmahera, Ternate, Kajoa, Bacan, Obi and Talaud), Waigeo and Weeim Island, D. ochrothorax Duffels, 1977 from Gebe Island and $D$. bacanensis Duffels, 1988 from Bacan. These Maluku Utara species form the sister-group of one species, D. obtecta (Fabricius, 1803) from Buru, Seram, Ambon and Sula. The sister-group of the whole obtecta group is found all over New Guinea and the Solomon Islands (Duffels, 1977, 1986).

The Baeturia conviva group, which consists of five species, has two species in Maluku Utara, B. conviva Stål, 1861 from Bacan and Obi and B. laureli De Boer, 1986 from Halmahera, 
which probably form the sister-group of one species, B. schulzi Schmidt, 1926 from Buru. The other species of the group are recorded from Tjendrawasih (=Vogelkop of New Guinea), the Aru Islands and Roon Island in the Geelvink Bay (De Boer, 1986).

The Cosmopsaltria doryca group shows a similar pattern of vicariance. C. halmaherae from Halmahera is supposed to be the sister-species of $C$. lata from Buru and Ambon. The sistergroup of these both species is $C$. doryca, which has a wide distribution in West New Guinea (Duffels, 1983).

In all these three species groups there is a sister-group relationship between taxa from Maluku Utara and Maluku Selatan, whereas the sister-groups of the Maluku taxa have a more eastern distribution in either Tjendrawasih or West New Guinea or New Guinea and the Solomon Islands. For some further remarks on the biogeography of cicadas from Maluku Utara the reader is referred to Duffels, 1988.

\section{ACKNOWLEDGEMENTS}

I thank Dr. S. Adisoemarto, Museum Zoologicum Bogoriense, Bogor and Dr. H. Schröder, Senckenberg Museum, Frankfurt am Main for the loan of material.
Dra. Anita Hannah and Dra. Rahayuningsih Suhardjono gave indispensable assistance during my stay in the Museum Zoologicum Bogoriense in 1985, for which I sincerely thank them. Mr. M. R. de Jong, Amsterdam, discovered two specimens of the new species in the Senckenberg Museum. A grant from the Netherlands Foundation for the Advancement of Tropical Research (WR 85-179) enabled me to study the collection of the Museum Zoologicum Bogoriense.

\section{REFERENCES}

BoER, A. J. DE, 1986. The taxonomy and biogeography of the conviva group of the genus Baeturia Stål, 1866 (Homoptera, Tibicinidae). Beaufortia, 36: 167-182.

Duffels, J. P., 1977. A revision of the genus Diceropyga Stăl, 1870 (Homoptera, Cicadidae). Monografieën Ned. ent. Vereen., 8: 1-227.

-_, 1983. Taxonomy, phylogeny and biogeography of the genus Cosmopsaltria, with remarks on the historic biogeography of the subtribe Cosmopsaltriaria (Homoptera, Cicadidae). Pacific Insects Monogr., 39: 1-127.

-, 1986. Biogeography of Indo-Pacific Cicadoidea: a tentative recognition of areas of endemism. Cladistics, 2: 318-336.

-, 1988 . Biogeography of the cicadas of the island of Bacan, Maluku, Indonesia with description of Diceropyga bacanensis n. sp. Tijdschr. Ent., 131: 7-12.

Lieftinck, M. A., 1953. Revisional notes on the genera Diplacina Brauer and Huonia Förster (Odon.). Treubia, 22: 153-216. 